\title{
Pengaruh atribut usia dan jenis kelamin dosen terhadap pemberian evaluasi oleh mahasiswa
}

Nur Julqurniati ${ }^{1}$ Jefri Setyawan ${ }^{2}$ Winny Aisyah Amini ${ }^{3}$ dan Sofyan Hadi Surya ${ }^{4}$

\begin{abstract}
The practice of giving evaluations from students to lecturers is often the moment when the halo effect occurs. Sex and age as individual attributes contribute to positive or negative evaluations of teaching evaluations. The purpose of this study is whether the attributes of age and sex interact with the halo effect in giving evaluations from students to lecturers. This research uses a one-shot case study with an online between-subjects design. One hundred twenty participants were divided into four groups. Each group evaluates 1 of 4 different photos (young men, older men, young women, and older women) labeled with the identity as a lecturer. The results of multiple linear regression analysis show: (1) The sex of the lecturer has no effect on student evaluation $(F=0.730, p=0.395)$; (2) Lecturer age has no effect on student evaluation $(F=0.587, p=0.445)$; (3) The interaction of sex and age has no effect on student evaluation $(F=0.649, p=0.525)$. The sex and age of the lecturer do not affect the evaluation by students. The halo effect did not occur in the students in this study.
\end{abstract}

\section{Keywords}

gender, halo effect, individual attributes, lecturer age, student evaluation

\section{Pendahuluan}

Evaluasi pembelajaran merupakan sebuah proses penting dalam menjaga dan meningkatkan kompetensi pengajar untuk keberhasilan peserta didik (Özcan, 2013). Kegiatan ini meliputi proses pengumpulan informasi tentang bagaimana dosen melakukan pengajaran, menginterpretasi informasi dan membuat evaluasi mengenai tindakan apa yang harus dilakukan untuk meningkatkan kualitasnya (Sutarman \& Simbolon, 2015). Pemberian evaluasi oleh mahasiswa terhadap dosen, seringkali menghadapi permasalahan yang sama, yaitu adanya bias gender (Sonnert et al., 2018). Penelitian MacNell et al. (2015) menemukan bahwa mahasiswa cenderung mendeskripsikan dosen lakilaki lebih cerdas, luar biasa, dan lebih berpengetahuan dibandingkan dengan dosen wanita, yang dipandang lebih suka memerintah dan menyebalkan, serta berpenampilan cantik atau jelek. Penelitian tersebut menemukan bahwa mahasiswa memberikan nilai yang lebih tinggi untuk dosen laki-laki terlepas dari kemampuannya dalam mengajar (MacNell et al., 2015). Tampaknya daya tarik fisik memberikan 'efek halo' pada kesan umum tentang dosen dan bias evaluasi pada atribut lain ke arah yang positif.

Efek halo pertama kali dikemukakan oleh Thorndike tahun 1920, yaitu terjadi ketika kesan global atau informasi tentang karakteristik yang menonjol mempengaruhi bagaimana sifat-sifat individu dinilai(Forgas \& Laham, 2017). Efeknya bekerja dalam dua arah, informasi positif menghasilkan sifat-sifat yang dievaluasi secara lebih positif dan informasi negatif mengarah pada sifat-sifat yang dievaluasi secara negatif (Gräf \& Unkelbach, 2016). Efek halo dapat dipicu oleh berbagai karakteristik sosial, seperti daya tarik fisik, status sosial, nama yang tidak biasa, gaya interpersonal, dan lain-lain (Forgas \& Laham, 2017). Penelitian lain menemukan bahwa evaluasi yang diberikan berfluktuasi sesuai karakteristik yang melekat, atas dasar pada harapan masyarakat yang tidak dapat diubah oleh individu, seperti gender dan proses penuaan (Wilson et al., 2014). Laporan pada web RateMyProfessor.com menemukan bahwa nilai lebih tinggi diberikan kepada dosen yang menjadi profesor tetap dari sebuah fakultas universitas tertentu, tidak memiliki aksen ketika sedang berbicara, berjenis kelamin laki-laki, dan berusia muda (Murray et al., 2020). Peneliti berasumsi bahwa pemberian evaluasi dalam proses pembelajaran tidak hanya ditentukan oleh bias gender, namun faktor usia dari dosen turut berkontribusi.

Usia dan jenis kelamin termasuk kategori sosial yang umumnya menjadi aspek pertama yang diperhatikan saat bertemu seseorang untuk pertama kalinya (Johnson

\footnotetext{
1,2,3,4 Fakultas Psikologi, Universitas Gadjah Mada
}

Korespondensi:

Nur Julqurniati, Fakultas Psikologi, Universitas Gadjah Mada Jl. Sosio Humaniora Bulaksumur, Karang Malang, Caturtunggal, Kec. Depok, Kabupaten Sleman, Daerah Istimewa Yogyakarta 55281

Email: njulqurniati@gmail.com 
et al., 2015). Usia dan jenis kelamin sebagai atribut individu seringkali membentuk persepsi mahasiswa dalam memberikan evaluasi kepada para pengajar. Idealnya siswa menilai pengajar berdasarkan kinerja mereka, apa yang mereka pelajari, bukan pada penampilan mereka (Pennington et al., 2020). Penelitian yang dilakukan oleh Bennett (1982) menemukan bahwa instruktur wanita dinilai lebih hangat dan lebih suportif daripada instruktur pria, dan hal ini menyebabkan peringkat instruktur wanita yang lebih tinggi pada keefektifan serta aspek-aspek lain dari kinerja mengajar secara umum. Mahasiswa juga mengharapkan dukungan interpersonal yang lebih besar dari pengajar perempuan dibandingkan dari pengajar laki-laki (Bennett, 1982). Pada studi lain, deskripsi profesor terbaik lebih sering adalah perempuan untuk mahasiswa perempuan daripada mahasiswa laki-laki (Basow, 2000). Studi yang dilakukan oleh MacNell et al. (2015) juga menemukan adanya pengaruh gender pengajar terhadap pemberian peringkat oleh siswa, dimana evaluasi lebih tinggi cenderung diberikan kepada pengajar laki-laki. Selanjutnya, studi eksperimen tentang persepsi usia pengajar yang dilakukan Arbuckle \& Williams (2003) menemukan bahwa siswa menganggap dosen lakilaki muda memiliki gaya berbicara lebih antusias dan menggunakan nada suara yang bermakna. Hal ini berbeda dengan temuan yang dilakukan oleh Pennington et al. (2020) menemukan bahwa usia berpengaruh terhadap evaluasi siswa, dimana para siswa lebih menyukai guru yang berusia setengah baya sebagai panutan dibandingkan guru yang berusia lebih muda.

Penelitian tentang efek halo berkembang di berbagai bidang penelitian, terutama dalam pekerjaan atau pengaturan berbasis pendidikan di mana evaluasi yang jujur dan tidak bias menjadi signifikan. Penelitian tersebut seperti efek potensial usia dan jenis kelamin dosen (Stonebraker \& Stone, 2015; Wilson et al., 2014), efek halo dan ceiling effect dalam evaluasi (Keeley et al., 2013), bias halo pada evaluasi (Malouff et al., 2014), dan efek halo terhadap perilaku siswa (Álvarez-García et al., 2004; Marucci et al., 2021). Hal berbeda terjadi di Indonesia, penelitian tentang efek halo lebih banyak berkembang dalam konteks non-psikologi, seperti kajian perilaku pasar modal (Djojopranoto \& Mahadwartha, 2016) dan efek halo pada merk (Sulhaini et al., 2019). Penelitian tentang efek halo dalam pendidikan ditemukan pada efek halo pada pengajar native Bahasa Inggris (Kramadibrata, 2015). Penelitian tersebut belum spesifik mengkaji usia dan jenis kelamin pengajar. Padahal, literatur yang berkembang sangat penting untuk merespon masalah yang terus-menerus terjadi dalam pemberian evaluasi terhadap dosen, yaitu bias usia dan jenis kelamin. Terjadinya bias evaluasi yang diberikan oleh mahasiswa berdasarkan usia dan jenis kelamin dapat merugikan para pengajar. Pengajar tidak mendapat evaluasi yang objektif mengenai kompetensi yang dimiliki. Padahal evaluasi mahasiswa dapat memandu pengajar untuk dapat menyesuaikan cara mengajar dan berinteraksi dengan siswanya (Ryan \& Wilson, 2014). Berdasarkan urgensi tersebut, penelitian ini dilakukan untuk mengetahui apakah atribut usia dan jenis kelamin pada dosen berinteraksi dengan efek halo dalam populasi mahasiswa di Indonesia. Dengan demikian, hipotesis penelitian ini yaitu; 1) ada peran jenis kelamin dosen terhadap evaluasi oleh mahasiswa; 2) ada peran usia dosen terhadap pemberian evaluasi oleh mahasiswa; dan 3) ada peran antara jenis kelamin dosen dan usia dosen terhadap evaluasi oleh mahasiswa.

\section{Metode}

\section{Subjek}

Pemilihan subjek dalam penelitian ini menggunakan teknik simple random sampling. Subjek yang bersedia terlibat penelitian sejumlah 119 mahasiswa dengan karakteristik mahasiswa aktif yang tinggal di Indonesia, berjenis kelamin laki-laki atau perempuan, jenjang pendidikan diploma (D3/D4), sarjana (S1) dan pascasarjana (S2). Usia subjek adalah 18-40 tahun. Berdasarkan jumlah tersebut, kemudian dilakukan acak menggunakan situs layanan acak di internet, random.org, untuk membagi 120 mahasiswa terpilih ke dalam 4 kelompok eksperimen.

\section{Desain Eksperimen}

Metode yang digunakan penelitian eksperimen dengan model One-Shot Case Study. Paradigma dalam penelitian eksperimen model ini yaitu: $\mathrm{X}=$ perlakuan yang diberikan (variabel bebas) $\mathrm{O}=$ Observasi (variabel terikat). Model eksperimen dapat dibaca sebagai berikut: terdapat suatu kelompok diberikan perlakuan dan selanjutnya diobservasi hasilnya (perlakuan sebagai variabel bebas, dan hasil sebagai variabel terikat) (Sugiono, 2011). Jenis kelamin dan usia dosen $(\mathrm{X})$ dan evaluasi mahasiswa terhadap dosen (Y).

\section{Alat dan Bahan}

Penelitian ini menggunakan 4 buah foto berwarna hitam dan putih, untuk menghindari bias warna pada perseorangan yang diberikan label sebagai seorang dosen. Foto tersebut terdiri dari 1 foto laki-laki dan 1 foto perempuan yang dimanipulasi menjadi 2 versi yaitu foto wajah yang merepresentasikan penuaan (seperti rambut putih dan beberapa kerutan pada wajah), yang selanjutnya kami sebut sebagai "dosen tua" dan versi foto wajah yang merepresentasikan dosen yang belum mengalami penuaan (rambut hitam dan tidak memiliki kerutan pada wajah), yang selanjutkan kami sebut sebagai "dosen muda".

Penelitian ini menggunakan alat ukur dengan 7 item dari (Goebel \& Cashen, 1979) untuk mengukur interaction, evaluation, overload, structure, skill, global dan rapport. item-item tersebut telah ditranslasi ke dalam bahasa Indonesia, antara lain: (1) dosen mendorong mahasiswa 
untuk mengajukan pertanyaan; (2) mengharapkan mahasiswa mengerjakan tugas dengan baik; (3) dosen memberikan banyak tugas; (4) dosen adalah orang yang terorganisir; (5) mampu menjelaskan materi kuliah; (6) menjadi dosen yang baik; dan (7) bersikap ramah terhadap mahasiswa. Masing-masing item diberikan evaluasi dengan rentang 1-10, 1 menunjukkan evaluasi "sangat tidak sesuai” hingga 10 menunjukkan "sangat sesuai".

\section{Prosedur Pengambilan Data}

Penelitian ini menggunakan empat kelompok eksperimen yang terdiri dari; (1) kelompok yang mengevaluasi foto dosen laki-laki muda, (2) kelompok yang mengevaluasi foto dosen laki-laki tua, (3) kelompok yang mengevaluasi foto dosen perempuan muda, dan (4) kelompok yang mengevaluasi foto dosen perempuan tua.

Pelaksanaan pengambilan data dilakukan secara daring melalui email dan google form. Pertama untuk mendapatkan partisipan, peneliti membagikan tautan yang berisikan identitas kesediaan berpartisipasi. Setelah pendaftar terkumpul, partisipan secara acak dibagi ke dalam empat kelompok eksperimen menggunakan random.org secara merata.

Setiap kelompok eksperimen terdiri dari 30 mahasiswa. Setelah pengacakan selesai, masing-masing peserta dihubungi via email dan diundang dengan mengirimkan tautan kuesioner yang sesuai dengan kelompok eksperimennya.

\section{Sorting task}

Peneliti menentukan dua orang (laki-laki dan perempuan) sebagai dosen dengan pertimbangan sebagai berikut: (1) tidak memiliki disabilitas dalam segi fisik pada area foto, seperti panca indra; (2) bebas dari penggunaan atribut keagamaan seperti jilbab pada perempuan; (3) tidak tampak tersenyum lebar pada foto. Masing-masing jenis kelamin, memiliki dua versi foto, yaitu foto terkini (dosen muda) dan foto modifikasi (dosen tua). Foto modifikasi berupa modifikasi dari foto terkini dosen, dengan memberikan efek rambut berwarna putih dan beberapa kerutan di wajah. Foto modifikasi disebut dengan foto dosen tua. Warna dihilangkan dalam foto untuk menghindari perbedaan persepsi, penglihatan, dan preferensi individu. Selanjutnya, terdapat empat foto hitam putih dipersiapkan dari foto yang mewakili dosen laki-laki muda, dosen laki-laki tua, dosen perempuan muda, dan dosen perempuan tua.

\section{Rating task}

Subjek dalam setiap kelompok dikirimkan satu tautan yang berisikan foto seseorang tanpa warna (hitam putih) yang dilabelkan sebagai Dosen. Subjek diminta memberikan rating atau evaluasi pada tujuh pernyataan kuesioner evaluatif pada saat foto dosen ditampilkan. Pernyataan tersebut berisikan evaluasi keseluruhan dari orang yang digambarkan sebagai seorang dosen (Goebel \& Cashen, 1979).

\section{Analisis Data}

Uji normalitas dan uji homogenitas dilakukan sebelum dilakukan uji regresi linear. Hasil uji normalitas menunjukkan bahwa nilai uji signifikan dengan Saphiro-Wilk $0.024<0.05$, artinya evaluasi dosen yang diberikan oleh mahasiswa tidak terdistribusi secara normal. Ketidaknormalan sebaran data dapat disebabkan oleh beberapa diantaranya adalah dekatnya jarak skor dengan nilai terbawah dan teratas, serta jenis data mengikuti distribusi yang berbeda dengan distribusi normal. Hal ini berdasarkan pendapat dari Darlington \& Hayes (2017) yang mengatakan bahwa peneliti dapat mengabaikan normalitas data, karena diantara seluruh syarat asumsi regresi normalitas data merupakan asumsi yang paling rendah menyumbang terhadap pengambilan kesimpulan. Berdasarkan hal tersebut peneliti tetap melanjutkan untuk melakukan uji regresi linear sederhana dan regresi linear berganda. Selanjutnya pada uji homogenitas menunjukkan nilai signifikansi yang diperoleh sebesar 0.024. Nilai signifikansi $0.024<0.05$ pengujian data mempunyai varian antar kelompok yang tidak homogen.

\section{Hasil \\ Uji statistika deskriptif}

Hasil statistika deskriptif pada Tabel 1 menunjukkan bahwa dari 119 partisipan penelitian, memberikan evaluasi yang berbeda terhadap dosen laki-laki muda dengan dosen laki-laki tua pada item pernyataan yang diberikan. Dosen laki-laki muda mendapat evaluasi tinggi $(M=4.2$, $s=2.7)$, sedangkan dosen tua mendapat evaluasi lebih rendah $(M=3.1, s=1.6)$, pada item "akan menjadi dosen yang baik". Dosen muda juga dinilai lebih tinggi ( $M=4.0$, $s=2.8)$ pada item "ramah terhadap mahasiswa" dibanding dosen tua $(M=3.2, s=2.0)$. Dosen laki-laki tua mendapat evaluasi lebih tinggi ( $M=4.2, s=2.7$ ) pada satu item pernyataan saja yaitu "mengharapkan mahasiswa mengerjakan tugas dengan baik" dibandingkan dosen muda $(M=4.0$, $s=2.5$ ). Pada dosen berjenis kelamin perempuan, hasil menunjukkan evaluasi yang hampir sama seperti pada dosen laki-laki. Mahasiswa memberikan evaluasi lebih tinggi pada 6 item pernyataan untuk dosen perempuan muda. Misalnya dosen perempuan muda mendapat evaluasi tinggi ( $M=3.6, s=1.6$ ) dibandingkan dosen perempuan tua $(M=3.1, s=1.6)$ pada item pernyataan "ramah terhadap mahasiswa. Dosen perempuan muda juga mendapat evaluasi tinggi $(M=4.2, s=3.0)$ dibandingkan dosen perempuan tua $(M=3.8, s=2.2)$ pada item pernyataan "mampu menjelaskan materi". Sedangkan dosen perempuan tua juga hanya mendapat satu evaluasi yang lebih tinggi $(M=3.8$, $s=2.2$ ) pada item pernyataan "dosen orang yang terorganisir (teratur)" dibanding dosen perempuan muda ( $M=3.6$, $s=2.3$ ). 
Tabel 1. Rata-rata dan simpangan baku dosen berdasarkan item pernyataan

\begin{tabular}{|c|c|c|c|c|c|c|c|c|}
\hline \multirow[b]{3}{*}{ Item Pertanyaan } & \multicolumn{4}{|c|}{ Laki-laki } & \multicolumn{4}{|c|}{ Perempuan } \\
\hline & \multicolumn{2}{|c|}{ Tua } & \multicolumn{2}{|c|}{ Muda } & \multicolumn{2}{|c|}{ Tua } & \multicolumn{2}{|c|}{ Muda } \\
\hline & M & $s$ & M & $s$ & M & $s$ & M & $s$ \\
\hline Mendorong untuk bertanya & 3.6 & 1.9 & 3.2 & 0.9 & 3.6 & 1.9 & 3.2 & 0.9 \\
\hline Mengharapkan tugas dikerjakan dengan baik & 4.0 & 2.5 & 4.2 & 2.7 & 3.8 & 2.6 & 3.8 & 2.2 \\
\hline Memberikan tugas terlalu banyak & 3.4 & 1.5 & 3.2 & 0.9 & 3.0 & 2.1 & 2.8 & 2.1 \\
\hline Dosen orang yang teratur & 3.8 & 2.6 & 3.6 & 1.9 & 3.6 & 2.3 & 3.8 & 2.2 \\
\hline Mampu menjelaskan materi & 4.2 & 2.7 & 3.8 & 2.2 & 4.2 & 3.0 & 3.8 & 2.2 \\
\hline Dosen yang baik & 4.2 & 2.7 & 3.1 & 1.6 & 3.8 & 2.2 & 3.6 & 1.9 \\
\hline Ramah terhadap mahasiswa & 4.0 & 2.8 & 3.2 & 2.0 & 3.6 & 1.9 & 3.1 & 1.6 \\
\hline
\end{tabular}

Tabel 2. Deskripsi rata-rata skor evaluasi mahasiswa

\begin{tabular}{lcc}
\hline Jenis Kelamin & $n$ & $M$ \\
\hline Laki-laki & 59 & 26.1 \\
Muda & 29 & 27.6 \\
Tua & 30 & 24.6 \\
Perempuan & 60 & 25.2 \\
Muda & 30 & 26.7 \\
Tua & 30 & 24.5 \\
\hline & 119 & 25.6 \\
\hline
\end{tabular}

Berdasarkan Tabel 2 dosen berusia muda mendapat evaluasi yang lebih tinggi dengan $M=26.7$ dibandingkan dosen berusia tua dengan $M=24.5$. Dosen laki-laki mendapat evaluasi yang lebih tinggi dengan $M=26.1$ dibandingkan dengan dosen perempuan dengan $M=25.2$. Selanjutnya dosen laki-laki muda memperoleh nilai lebih tinggi dengan $M=27.6$ dibandingkan dosen perempuan muda yang memperoleh nilai $M=26.7$. Sedangkan pada dosen tua masing-masing mendapatkan evaluasi yang tidak jauh berbeda yaitu laki-laki dengan $M=24.6$ dan perempuan dengan $M=24.6$.

Pada Tabel 3 peran jenis kelamin terhadap evaluasi mahasiswa pada dosen memperoleh nilai $\mathrm{F}=0.73, \mathrm{p}=$ 0.395 , sehingga dapat diartikan bahwa jenis kelamin tidak berperan secara signifikan terhadap evaluasi mahasiswa pada dosen. Selanjutnya, peran usia dosen terhadap evaluasi mahasiswa memiliki nilai $\mathrm{F}=0.59, \mathrm{p}=$ 0.445. Dengan demikian usia dosen tidak berperan secara signifikan terhadap evaluasi mahasiswa pada dosen. Analisis regresi linier juga menunjukkan jenis kelamin dan usia dosen terhadap evaluasi mahasiswa memperoleh nilai $\mathrm{F}=0.65, \mathrm{p}=0.55$. Hal ini berarti bahwa tidak ada

Tabel 3. Hasil uji regresi linear sederhana

\begin{tabular}{lcccc}
\hline & $r$ & $R^{2}$ & $F$ & $p$ \\
\hline Jenis kelamin & .079 & .006 & .730 & .395 \\
Usia & .071 & .005 & .587 & .445 \\
Jenis kelamin \& Usia & .105 & .011 & .649 & .525 \\
\hline
\end{tabular}

interaksi antara jenis kelamin dan usia dosen terhadap evaluasi mahasiswa pada dosen.

\section{Pembahasan}

Hasil penelitian ini menemukan tidak terdapat peran pemberian evaluasi oleh mahasiswa berdasarkan jenis kelamin dosen. Temuan ini bertolak belakang dengan beberapa penelitian sebelumnya, seperti Pohl (2017) yang menyebutkan bahwa terdapat bias gender dalam pemberian evaluasi pengajar oleh siswa dan Anderson (2010) yang menemukan bahwa mahasiswa menggunakan jenis kelamin sebagai standar dalam pemberian evaluasi terhadap dosen.

Hasil penelitian ini justru mendukung penelitian yang dilakukan oleh Ryan \& Wilson (2014) yang menemukan bahwa jenis kelamin pengajar tidak secara signifikan memberikan peran evaluasi peserta didik terhadap pengajar. Pada penelitian ini perbedaan evaluasi menunjukkan selisih yang sedikit, sehingga tidak signifikan menunjukkan adanya bias jenis kelamin (lihat Tabel 1). Hasil ini menunjukkan adanya kemungkinan pergeseran stereotip gender yang melekat pada suatu profesi. Jika pada temuan terdahulu dosen perempuan dipandang lebih negatif daripada laki-laki dalam pengaturan akademis, namun pandangan ini tergantung pada ekspektasi gender serta bidang akademik dan kepekaan informasi yang disajikan (Abel \& Meltzer, 2007). Temuan ini memperkuat adanya pergeseran stereotip mengenai dosen laki-laki dan perempuan, sehingga dosen perempuan mendapat evaluasi yang tidak jauh berbeda dengan dosen laki-laki. Hal ini juga bisa disebabkan sikap yang lebih liberal terhadap ekspektasi stereotip gender, sehingga mempengaruhi evaluasi mahasiswa terhadap dosen (Abel \& Meltzer, 2007).

Penelitian ini juga menemukan bahwa tidak terdapat peran pemberian evaluasi oleh mahasiswa berdasarkan usia dosen. Berdasarkan uji deskriptif statistik, terdapat perbedaan evaluasi terhadap dosen muda dengan dosen tua, namun perbedaan tersebut tidak signifikan dalam memberikan peran evaluasi mahasiswa terhadap dosen. Temuan ini sejalan dengan penelitian yang dilakukan (Sonnert et al., 2018) yang menemukan bahwa usia memiliki pengaruh 
negatif tetapi tidak signifikan terhadap evaluasi dosen yang dilakukan oleh mahasiswa. (Spooren, 2010) menggunakan RateMyProfessor juga menemukan bahwa meskipun penuaan menyebabkan perbedaan evaluasi terhadap dosen, tetapi perbedaan tersebut memiliki dampak yang kecil untuk menjadi isu yang signifikan. Selain itu, kategori usia mahasiswa pada penelitian ini berada pada rentang usia 1840 tahun, dimana ada kecenderungan seiring bertambahnya usia dan kedewasaan peserta didik, mendorong mereka lebih sedikit menilai secara bias berdasarkan usia dosen. Kedewasaan mereka memberikan kesadaran bahwa semua dosen dari segala usia memiliki keefektifan yang setara (Özcan, 2013).

Selanjutnya, interaksi antara jenis kelamin dengan usia dosen tidak memberikan peran pada pemberian evaluasi oleh mahasiswa. Pada penelitian ini dosen laki-laki muda mendapat evaluasi paling tinggi jika dibandingkan dengan dosen laki-laki tua, maupun dosen perempuan muda dan tua. evaluasi terhadap dosen laki-laki muda memiliki sedikit perbedaan dari dosen perempuan muda. Temuan ini menunjukkan perbedaan yang tidak signifikan, sehingga dapat diartikan tidak terjadi bias berdasarkan jenis kelamin dan usia ketika mahasiswa memberikan evaluasi evaluasi pada dosen. Hasil penelitian ini bertentangan dengan penelitian sebelumnya, seperti (Gräf \& Unkelbach, 2016), (Thorndike, 1920), dan (Johnson et al., 2015).

Penelitian ini justru menemukan bahwa perbedaan jenis kelamin dan usia yang diprediksi akan memberikan efek halo tidak terjadi pada mahasiswa dalam penelitian ini. Hasil ini bisa dikaji dengan beberapa alasan spesifik. Pertama, proses terjadinya efek halo berkaitan dengan jenis strategi pemrosesan informasi yang dimiliki oleh partisipan. Partisipan menentukan strategi apa dalam merespon sebuah stimulus. Pada proses tayangan foto dibentuk dengan cara yang sederhana, otomatis, dan heuristik, kita mungkin mengharapkan efek halo terjadi dan bisa berkembang. Sebaliknya, pada pemrosesan informasi yang lebih hati-hati, sistematis dan penuh atensi dapat mengurangi efek halo. Eksperimen yang dilakukan oleh Djojopranoto \& Mahadwartha (2016) menemukan bukti spesifik yang mendukung asumsi ini. Gaya pemrosesan informasi dimanipulasi secara tidak langsung dengan menginduksi suasana hati positif atau negatif pada partisipan. Suasana hati yang positif menghasilkan proses yang lebih heuristik dan konstruktif, sedangkan suasana hati negatif menghasilkan gaya berpikir yang lebih sistematis dan penuh atensi Djojopranoto \& Mahadwartha (2016). Pada penelitian ini, adanya kemungkinan evaluasi dilakukan saat partisipan berada pada kondisi suasana hati negatif sehingga mengurangi efek halo. Selanjutnya, dari temuan ini kami bisa menjelaskan bahwa partisipan benar-benar memproses informasi yang rasional, tidak bias dan bebas dari ilusi kognitif apapun, sehingga tidak dapat terjadi efek halo terhadap mereka.

Penelitian ini menegaskan bahwa tidak terjadi efek halo yang terkait usia dan jenis kelamin dosen dalam konteks evaluasi terhadap dosen. Penjelasan komplementer dan lebih relevan dari efek halo yang spontan dapat didasarkan pada associative network theory dan gagasan spreading activation theory di antara atribut yang terkait. Pada istilah fungsional, akumulasi pengalaman individu menyebabkan atribut atau kualitas tertentu menjadi lebih atau kurang terkait erat satu sama lain dalam ingatan. Penyajian dan aktivasi suatu atribut, seperti usia dan jenis kelamin, akan secara otomatis dan terjadi seleksi, kemudian proses aktivasi penyebaran hingga mengakses atribut lain yang sebelumnya terkait. Misalnya, dalam hal ini yaitu kemampuan mengajar, cara penugasan, perilaku ramah, dan lain-lain. Tidak terjadinya efek halo bisa dikarenakan kurang kuatnya asosiasi pengalaman mengenai atribut tertentu dengan atribut yang dinilai (dalam hal ini usia dan jenis kelamin dosen) dalam ingatan partisipan.

\section{Simpulan}

Penelitian ini menemukan bahwa tidak terjadi efek halo yang terkait usia dan jenis kelamin dosen dalam konteks evaluasi mahasiswa terhadap dosen. Tidak adanya efek halo pada penelitian ini dijelaskan oleh beberapa alasan. Pertama, terkait strategi pemrosesan informasi yang berkaitan dengan suasana hati partisipan. Kedua, partisipan berada dalam kondisi rasional, tidak bias dan bebas dari ilusi kognitif saat penelitian berlangsung, Terakhir, kurang kuatnya asosiasi pengalaman partisipan mengenai atribut tertentu dengan atribut yang dinilai.

Penelitian ini memiliki beberapa keterbatasan, yaitu pertama, data yang dikumpulkan dari 119 responden merupakan data yang tidak terdistribusi secara normal dan tidak homogen. Kedua, eksperimen ini dilakukan secara daring, sehingga peneliti tidak dapat melakukan kontrol terhadap variabel atau kondisi lain yang dapat mempengaruhi hasil eksperimen. Ketiga, penelitian ini tidak melakukan standarisasi dalam pemilihan foto dan tidak melakukan try out sebelum menggunakan fotofoto untuk eksperimen. Penelitian selanjutnya diharapkan memperhatikan ketiga aspek keterbatasan tersebut dalam melakukan replikasi penelitian ini.

\section{Referensi}

Abel, M.H., \& Meltzer, A. L.(2007). Student rating of a male and female professors' lecture on sex discrimination in the workforce. Sex Roles, 57, 173-180. https://doi.org/10.1007/ s11199-007-9245-x

Álvarez-García, D., García, T., \& González-Castro, P. (2014). Halo effect of student misbehavior on teacher ratings of impulsivity and other executive function deficits. In M. C. Olmstead (Ed.), Psychology of emotions, motivations and actions. Psychology of impulsivity: New research (p. 21-31). Nova Science Publishers.

Anderson, K.J. (2010). Students' stereotypes of professors: an exploration of the double violations of ethnicity and gender. 
Social Psychology of Education, 13(4), 459-472. https://doi. org.ezproxy.ugm.ac.id/10.1007/s11218-010-9121-3

Arbuckle, J., \& Williams, B. D. (2003). Students' perceptions of expressiveness: Age and gender effects on teacher evaluations. Sex Roles, 49(9/10), 507-516. https://doi.org/10. 1023/A:1025832707002

Basow, S. A. (2000). Best and worst professors: Gender patterns in students' choices. Sex Roles, 43 (5/6), 407-417. https: //doi.org/10.1023/A:1026655528055

Bennett, S. K. (1982). Student perceptions of and expectations for male and female instructors: Evidence relating to the question of gender bias in teaching evaluation. Journal of Educational Psychology, 74(2), 170-179. https://doi.org/10. 1037/0022-0663.74.2.170

Darlington, R. B., \& Hayes, A. F. (2017). Regression Analysis and Linear Models. The Guildford Press

Djojopranoto, R. R., \& Mahadwartha, P. A. (2016). Pengujian bias perilaku: Gambler's fallacy, halo effect, dan familiarity effect di pasar modal Indonesia. Jurnal Akuntansi dan Keuangan Indonesia, 13(2), 18. http://dx.doi.org/10.21002/ jaki.2016.08

Forgas, J. P., \& Laham, S. M. (2017). Halo effects. In R. F. Pohl (Ed.), Cognitive illusions: Intriguing phenomena in thinking, judgment and memory (p. 276-290). Routledge/Taylor \& Francis Group.

Gräf, M., \& Unkelbach, C. (2016). Halo effects in trait assessment depend on information valence: Why being honest makes you industrious, but lying does not make you lazy. Personality and Social Psychology Bulletin, 42 (3), 290-310. https://doi.org/10.1177/0146167215627137

Goebel, B. L., \& Cashen, V. M. (1979). Age, sex, and attractiveness as factors in student ratings of teachers: A developmental study. Journal of Educational Psychology, 71 (5), 646-653. https://doi.org/10.1037/0022-0663.71.5.646

Johnson, K.L., Lick, D.J., \& Carpinella, L.M. (2015) Emergent research in social vision: an integrated approach to the determinants and consequences of social categorization. Social and Personality Psychology Compass, 9(1), 15-30. https://doi.org/10.1111/spc3.12147

Joye, S.W., \& Wilson, J.H. (2015). Professor age and gender affect student perceptions and grades. Journal Scholarship of Teaching and Learning, 15(4), 126-138. https://doi.org/10. 14434/josotl.v15i4.13466

Keeley, J. W., English, T., Irons, J., \& Henslee, A. M. (2013). Investigating halo and ceiling effects in student evaluations of instruction. Educational and Psychological Measurement, 73(3), 440-457. https://doi.org/10.1177/0013164412475300

Kramadibrata, A. (2015). The Halo surrounding native English speaker teachers in Indonesia. Indonesian Journal of Applied Linguistics, 5(2), 16. https://doi.org/10.17509/ijal.v5i2.1352

MacNell, L., Driscoll, A., \& Hunt, A. N. (2015). What's in a name: Exposing gender bias in student ratings of teaching. Innovative Higher Education, 40(4), 291-303. https://doi. org/10.1007/s10755-014-9313-4
Malouff, J. M., Stein, S. J., Bothma, L. N., Coulter, K., \& Emmerton, A. J. (2014). Preventing Halo bias in grading the work of university students. Cogent Psychology, 1(1), 988937. https://doi.org/10.1080/23311908.2014.988937

Marucci, E., Oldenburg, B., Barrera, D., Cillessen, A. H. N., Hendrickx, M., \& Veenstra, R. (2021). Halo and association effects: Cognitive biases in teacher attunement to peernominated bullies, victims, and prosocial students. Social Development, 30(1), 187-204. https://doi.org/10.1111/sode. 12455

Murray, D., Boothby, C., Zhao, H., Minik, V., Bérubé, N., Larivière, V., \& Sugimoto, C. R. (2020). Exploring the personal and professional factors associated with student evaluations of tenure-track faculty. PLOS ONE, 15(6), e0233515. https://doi.org/10.1371/journal.pone.0233515

Özcan, K. (2013). Student evaluation of lecture and teaching effectiveness in higher education. Academic Journals, 8(8), pp. 378-389, 12. https://doi.org/10.5897/ERR2013.1154

Pennington, C.G., Matthew D. C., Stefanie A. W. (2020). Influence of a physical education teacher's perceived age on high school pupils' perceptions of effectiveness and learning. European Physical Education Review. 26 (1), 22-35. https: //doi.org/10.1177/1356336X18816342

Pohl, R. (Ed.). (2017). Cognitive illusions: Intriguing phenomena in judgment, thinking and memory (Second edition). Routledge, Taylor \& Francis Group.

Potvin, G., Hazari, Z., Tai, R. H., \& Sadler, P. M. (2009). Unraveling bias from student evaluations of their high school science teachers. Science Education, 93(5), 827-845. https: //doi.org/10.1002/sce.20332

Ryan, R., \& Wilson, J. H. (2014). Professor-student rapport scale: Psychometric properties of the brief version. Journal of the Scholarship of Teaching and Learning, 14(3), 64-74. https: //doi.org/10.14434/josotl.v14i3.5162

Sonnert, G., Hazari, Z., \& Sadler, P. M. (2018). Evaluating the quality of middle school Mathematics teachers, ssing videos rated by college students. Studies in Educational Evaluation, 58, 60-69. https://doi.org/10.1016/j.stueduc.2018.05.006

Spooren, P. (2010). On the credibility of the judge: A crossclassified multilevel analysis on students' evaluation of teaching. Studies in Educational Evaluation, 36(4), 121-131. https://doi.org/10.1016/j.stueduc.2011.02.001

Stonebraker, R. J., \& Stone, G. S. (2015). Too old to teach? The effect of age on college and university professors. Research in Higher Education, 56(8), 793-812. https://doi. org/10.1007/s11162-015-9374-y

Sugiono. (2011). Metode Penelitian Kuantitatif Kualitatif dan R\&D. Alfabeta.

Sulhaini, S., Rinuastuti, B. H., \& Sakti, D. P. B. (2019). The halo effect of foreign brands on the misclassification of local brands, management \& marketing. Challenges for the Knowledge Society, 14(4), 357-371. https://doi.org/10.2478/ mmcks-2019-0025

Sutarman, S. \& Simbolon, M. (2015). Aplikasi evaluasi kinerja dosen di stmik bina sarana global. Jurnal Sisfotek Global, 5 
(1), 78-80. ttp://dx.doi.org/10.38101/sisfotek.v5i1.70

Thorndike, E. L. (1920). A constant error in psychological ratings. Journal of Applied Psychology, 4(1), 25-29. https: //doi.org/10.1037/h0071663

Wilson, J. H., Beyer, D., \& Monteiro, H. (2014). Professor age affects student ratings: Halo effect for younger teachers.
College Teaching, 62(1), 20-24. https://doi.org/10.1080/ 87567555.2013.825574

Wilson, J. H., \& Ryan, R. G. (2013). Professor-student rapport scale: Six items predict student outcomes. Teaching of Psychology, 40(2), 130-133. https://doi.org/10.1177/ 0098628312475033 